\begin{tabular}{|c|l|}
\hline Title & $\begin{array}{l}\text { Tourism Relationship Model and Intermediary for Sustainable Tourism Management : Case Study of the Kiritappu } \\
\text { Wetland Trust in Hamanaka, Hokkaido }\end{array}$ \\
\hline Author(s) & Shikida, A sami; Y oda, Mami; Kino, A kiko; Morishige, Masay uki \\
\hline Citation & BEST EN Think Tank IX: The Importance of V alues in Sustainable Tourism, 382-394 \\
\hline Issue Date & 2009-06-15 \\
\hline Doc URL & http://hdl.handle.net/2115/39472 \\
\hline Type & proceedings \\
\hline Note & Think Tank IX "The Importance of V alues in Sustainable Tourism". 15-18 June 2009. Singapore. \\
\hline File Information & Shikida_ThinkT ankIX.pdf \\
\hline
\end{tabular}

Instructions for use 


\title{
Tourism Relationship Model and Intermediary for Sustainable Tourism Management: Case Study of the Kiritappu Wetland Trust in Hamanaka, Hokkaido
}

\author{
Asami Shikida*, Mami Yoda ${ }^{\circ}$, Akiko Kino \& Masayuki Morishige \\ * Hokkaido University, Japan, shikida@cats.hokudai.ac.jp \\ - Hokkaido University, Japan, mami.yoda@alum.mit.edu
}

\begin{abstract}
This paper proposes a simple model that depicts the relationship between community and extra-community stakeholders that will enable the effective development of sustainable tourism. "Sustainable tourism" in this paper is defined as tourism that utilizes community resources for tourism development and re-invests the returns from tourism to the destination resources. The tourism relationship model, with a community-based intermediary as its subsystem, is introduced and applied to a case in Hokkaido, Japan. The application demonstrates that the model is a valid tool to identify two important factors for successful development of sustainable tourism, which are a "circulation mechanism" that connects community resources and extra-community stakeholders through community-based intermediaries, and a "balancing mechanism" that considers the existence value and economic value, supplemented by the community-based intermediary's functions to transfer financial and technology capital from non-tourist sources.
\end{abstract}

\section{Introduction}

Sustainable tourism is increasingly recognized as a common social goal for communities, not only in developing countries but also for developed economies. Expectations for sustainable tourism in Japan are also very high, because of the rising interest in the conservation of the natural environment, a trend that began accelerating during the 1990s after the Earth Summit in Rio de Janeiro, as well as by the economic challenges that many rural communities face.

Ecotourism, a sub-category of sustainable tourism, is perceived by many Japanese rural communities as a new way to attract visitors and stimulate local economies through generating tour revenues while conserving the natural, social, and cultural resources of communities. As a result, many communities have started to develop ecotours. However, the development of ecotourism does not automatically lead to conservation of community 
resources, and may in fact lead to additional environmental burdens, if not managed properly (Weaver, 2006).

Rural communities that are trying to develop ecotourism are also challenged by the need to understand and manage the complex relationship between community and extra-community stakeholders. This is an essential element of sustainable tourism because the involvement of extra-community stakeholders, who tend to focus on maximizing economic value, could overuse the existence value of community resources. In this sense, community autonomy, or initiatives undertaken by community stakeholders to develop tourism, is regarded as an important factor to enhancing sustainable tourism (Ishimori 2001, 2002; Shikida, et.al. 2008).

Despite such needs for community-based tourism development, there have been few practical solution-based models for community-based sustainable tourism. Past tourism models focused mainly on flows of tourists, not on the interrelationships of community and extra-community stakeholders.

The purpose of this article is to propose a simple model that depicts the relationship between community and extra-community stakeholders that will enable the effective development of sustainable tourism. The concept of a community-based intermediary, as a sub-system to the model, is introduced and applied to a case in Hokkaido, Japan. In order to analyze relatively small-scale tourism such as community-based ecotourism, this study mainly focused on activities in a relatively small area, namely municipalities, such as cities, towns, and villages, as well as smaller communities within each of them.

\section{Study Methodology}

The authors propose a hypothetical tourism relationship model and intermediary as illustrated through a case study of the Kiritappu Wetland Trust (hereinafter referred to as "the Trust"), located in Hamanaka, east of Hokkaido (northern island in Japan). The authors visited the Trust three times from January to November 2008. Community stakeholders, including staff members of the Trust, officials from the local government, and other community members, were repeatedly interviewed by the authors. In addition, an intensive study of the local economy and industries such as fishing and dairy farming was carried out.

The Trust is considered to be a suitable example to discuss the relationship between sustainability and community autonomy since various community groups work together under the Trust to provide ecotours. The Trust also has a 20-year track record in the promotion of ecotourism, and is regarded as one of the best ecotour providers in Japan, being a repeat winner of the Ecotourism Award presented by the Ministry of the Environment. 
In this article, the term "tourism system" is used as a system consisting of destination resources, community-based intermediaries, and extra-community stakeholders. The term "stakeholder" stands for those individuals and institutions, which have an interest in relation to certain developments and activities in the community, extra-community stakeholders being those located outside of the community.

\section{Background}

This section summarizes the social, political, and economic environments that explain the rising interest of ecotourism in Japan as well as the issues local communities need to address to develop sustainable tourism.

\section{Ecotourism Attracting Increasing Interest}

Interest in ecotourism comes from two sources. The first is a pursuit for environmental sustainability, which has been accelerating since the 1990s. Part of this was driven by the rapid deterioration of many local natural environments during Japan's high economic growth period from the 1960s to the 1980s, as a result of short-term, profit-oriented, and poorly planned development. This was mainly caused by the lack of recognition of the existence value of the natural environment as well as the focus on "monetizing" the economic value of natural resources.

The second source is the local communities' need to attain economic sustainability. Rural communities in Japan have been experiencing economic decline relative to urban areas due to the increasing urbanization and industrialization policies of the central government that began in the 1960s (Fujita, Tabuchi 1997) This was accelerated by globalization and deregulation that began in the 1980s, which made it difficult for small local economies to compete in a strictly market-based system. At the same time, Japan has entered an era of slower growth since the 1990s, which has been further exasperated by a declining birthrate and rapidly aging population (www.npo-homepage.go.jp). It should be also noted that the gap in economic and population growth has been widening between large urban centers and rural communities.

Furthermore, local communities have been forced to adopt more self-sustaining development policies as a gradual shift toward decentralization has taken place since 2003. Decreasing subsidies and tax transfers from the central government and less public works projects have created the impetus for a larger number of communities in Japan to initiate community-based development to revive their local economies, which has led to increased 
interest in ecotourism. In response to the growing popularity and importance of ecotourism, the Japanese government enacted the Ecotourism Promotion Act in 2006, which is designed to actively promote community based ecoturism mainly in rural areas in Japan.

\section{Issues on Governance and Community-Based Tourism}

There are other social and political issues that need to be taken into consideration when discussing sustainable tourism development in Japan.

The first such issue is the heightened need to understand the notion of "governance" in response to the increase in community-based activities in Japan. For example, activities of NPOs have been legitimated since the enactment of Japan's Non-profit Organization Act in 1998. Between December 1998 and March 2009, more than 37,000 NPOs have obtained approval for establishment from the government (Cabinet Office, Government of Japan 2009). Local governments started recognizing community-based activities as important driving forces to community management.

The second issue is to understand the influences of extra-community stakeholders, who look to maximize their economic output by utilizing community resources. Large-scale tourism development often necessitates the involvement of these extra-community shareholders, given the extensive investment required.

This leads to the third issue, which is to understand the relationship between the community and extra-community stakeholders, given that community autonomy cannot be achieved independent of the interaction with extra-community stakeholders. In today's world, communities are interdependent, both economically and socially, as exemplified by the Internet and transportation/communication systems. The creation of a mutually beneficial relationship between the community and extra-community stakeholders is therefore an essential element of sustainable development.

\section{Proposed Relationship Model}

In order to describe effective governance of sustainable tourism, the authors first propose a tourism relationship model, which is made up of three components: destination resources, extra-community stakeholders, and an intermediary (Figure 1). The first component includes human resources in the destination community in addition to the local natural and cultural resources, which can be turned into tourist attractions. The second component includes tourists and travel agencies located outside the community. The third component, 
"intermediary", represents a community-based organization or mechanism that connects the first two components.

Whether an intermediary is "community-based" or not is considered to be significant in understanding community autonomy and its impact on the relationship between the community and extra-community stakeholders. Accordingly, an "intermediary" in this relationship model is defined as a community-based organization or sub-system, and will hereafter be referred to as a "community-based intermediary (CBI)". This will also help to avoid confusion between a CBI and "intermediary". The latter term is often used in the tourism industry to refer to "travel agencies". In this model, travel agencies are linked with their client tourists, and grouped together as extra-community stakeholders, who are regarded as counterparts providing business opportunities and market information to community stakeholders.

The role of the $\mathrm{CBI}$ in the relationship model is as follows. In Step 1, it transforms community resources into tourism products. In Step 2 , the intermediary promotes and sells the products to consumers and/or travel agencies. In Step 3, the intermediary facilitates the acceptance of tourists, including the transportation of tourists from origination to destination, followed by various consumption activities in the region, which allows the destination community to generate economic returns. While the tourism process typically ends here, the relationship model identifies a fourth step (Step 4), which is the process of community reinvestment that enables the further development or enhances the value of destination resources, including natural, cultural, and human resources.

As such, the tourism relationship model is a mechanism that continually adjusts the relationship between the destination resources and the extra-community stakeholders through a circular flow. The model helps to examine the following two factors that are considered to be crucial for autonomous and sustainable tourism development. The first is whether a proper connection exists between community and extra-community stakeholders to enable the proper flow from production (value addition) to reinvestment of destination resources as shown in Figure 1.

Another factor is to control the volume of the tourist flow to achieve the long-term sustainability of the destination resources from a natural, social, and cultural perspective, while ensuring the necessary level of financial and knowledge capital for re-investment. Here, the most critical goal for the $\mathrm{CBI}$ is conservation, which requires a deep understanding of the existence value of the destination resources and a strong incentive and commitment to their conservation as a community stakeholder. The $\mathrm{CBI}$ places the highest priority in controlling the tourist flow at or below the level acceptable for conservation. If the financial 
and knowledge capital acquired through the tourist flow at the acceptable level is not large enough to ensure conservation, the $\mathrm{CBI}$ attempts to find a way to connect the non-tourist stakeholders and destination resources to fill the gap (Figure 2). In this way, the CBI also supports the destination resources to further upgrade their economic value by passing through such non-tourist financial and knowledge capital that can be used for necessary reinvestment to conduct value-added activities.

\section{Case Study: Kiritappu Wetland Trust}

\section{Introduction to the case}

The tourism relationship model was applied to the Kiritappu Wetland Trust, located in Hamanaka, Hokkaido, Japan, to examine the mechanism by which a local community could develop ecotourism in an autonomous and sustainable way.

Hamanaka, with about 6,800 people, is a small township in Hokkaido (Figure 3). The town began developing 150 years ago when the Japanese government commenced intensive fishery and agricultural development in Hokkaido. Since then, the town has flourished through its rich coastal fishery resources such as seaweed and sea urchins. The town is home to the Kiritappu Wetland, which covers about 3,168 ha with rich flora and fauna. The wetland is the third largest in Japan, after Kushiro and Sarobetsu, and was registered in the Ramsar List of Wetlands of International Importance in 1993.

The main industries of Hamanaka are fishing (24.3\% of households), dairy farming $(9.4 \%$ of households) and forestry (4.4\% of households). The fishing industry, which is carried out in the coastal areas close to the Kiritappu Wetland, employed 1,179 residents as of 2006, generating annual revenue of $\backslash 4.3$ billion. Of that, approximately $\backslash 1.4$ billion was generated from konbu seaweed. In dairy farming there are more than 22,000 milk cows, which generated more than 18.4 billion in revenue in 2004. Milk produced in Hamanaka is renowned for its high quality. Häagen-Dazs, makers of the super-premium ice cream, is listed among the town's key customers.

The wetland had been used for dairy farming and fishing because it was thought to hold no other economic value. However, the wetland also represented the heart and soul of the community, with many of its residents growing up enjoying the natural environment, thereby having a high existence value for the residents. 


\section{Historical evolution}

The Kiritappu Wetland Trust was established as a non-profit organization (NPO) in 2000. However, its origin goes back to a small gathering, "The Kiritappu Wetland Lovers", started by three people in 1984. The key person was Mr. Itoh, who was originally from Tokyo and moved to Hamanaka in 1983 after retiring. Mr. Itoh was running a teahouse in Kiritappu, and his regular customers consisted of members of the Kiritappu Wetland Lovers, totaling about 20. Their main activities consisted of enjoying the wetland by organizing picnics, barbecues, and cross-country skiing events. Their motto was "enjoy the wetland, because it is such an amazing place". This reflected their understanding and appreciation of the existence value of the wetland. Conservation was not one of their initial goals. However, as the environment of the wetland started to erode with the increasing amount of littering and new home construction, the members decided to shift their focus to conservation of the wetland. They decided to dissolve the Kiritappu Wetland Lovers, and organize the "Kiritappu Wetland Fan Club" in 1986.

The main purpose of this organization was to promote the conservation through positive actions, rather than protectionist-like activities. Their activities, which took place over a 13year period from 1986 to 1999, can be grouped into three categories: 1) leasing the wetland for conservation purposes, 2) direct investment of facilities used for conservation activities, such as site hardening, and 3) public relations, such as publication of newsletters.

The organization gained much recognition, receiving the prestigious Asahi Forest Culture Award in 1992, followed by the registration of the wetland to the Ramsar List of Wetlands in 1993. These helped to justify their activities within the community (Miyauchi 2006) and increase the number of members to approximately 4,000 .

At the same time, the town of Hamanaka opened the Kiritappu Wetland Center (the Center), and appointed Mr. Itoh as head of the Center. "Friends of the Kiritappu Wetland Center" (FKWC ) was established to provide operational services for the Center. FKWC operated a museum shop and a coffee shop at the Center, and the Center offered educational programs and ecotours. FKWC played a key role connecting the destination resources and tourists at its shop by transforming natural resources into concrete tourism services and products.

The activities of FKWC continued from 1992 until 2005, when the Center operation was turned over to a town and the Trust was appointed as an administrator. However, during the 13 years of the FKWC, the average number of visitors to the Center was over 40,000, and at its peak, sales from ecotours alone accounted for over 16 million. 


\section{Activities of the Trust}

Following the dissolution of the "Kiritappu Wetland Fan Club", the Kiritappu Wetland Trust was established in 2000 as an NPO. Its mission was to conserve the wetland and offer environmental education. The trust was appointed by the town as an administrator of the Center in 2005, and became an organization, which operates the center and provides various services, including ecotours.

The Trust conducts activities in four major categories. The first is to conserve the wetland. The Trust purchased 440 ha of the 1,200 ha as of 2008 . The second is to revive the natural resources in the area, such as reclaiming landfilled portion of the wetland. The third is to conduct research on the fauna and flora of the wetland. The fourth is to increase the number of supporters of the wetland through educational activities and ecotours, which goes back to its origin, the Kiritappu Wetland Lovers.

The Trust currently employs five staff to offer ecotours. Ecotours are one of the major activities of the Trust, generating over 17 million in 2007. The Trust spends a part of the ecotour revenue, together with a portion of other earnings, for the purchase of the wetland.

\section{Application of the Relationship Model}

Figure 4 explains how the tourism relationship model applies to the ecotourism operation of the Trust. Based on its mission to conserve the wetland, the Trust identifies the value of the wetland, develops ecotours, and sells the tours at the Wetland Center (Step 1 and 2). In the next step, the Trust (in practice, the Center) offers ecotours to tourists from outside the community. A portion of the revenue generated from ecotours is re-invested in the wetland through the purchase of additional wetland, thereby increasing the value of the community resource (Step 4).

As captured by the model, the salient feature of the tourism process of the Kiritappu Wetland Trust is the circular mechanism from Steps 1 through 4, with the Trust playing the role of intermediary that drives the process. This circulation mechanism is the key to sustainable tourism, allowing for value-added activities, such as the purchase of more wetland, as well as the utilization of the wetland through ecotour promotions. The purchase of the wetland also contributes to the control of the tourism traffic flow, thereby balancing the economic values and existence values, another critical element for sustainable tourism.

The Trust also supports the community to balance the economic values and existence values by connecting non-tourist stakeholders and destination resources. Namely, the Trust receives consignment business from the town, donations from the private sector, and trust 
membership fees to fill the gap between the investments necessary for the conservation of the destination resources and to continue increasing the value of the resources. The optimal mix of funding sources is beyond the scope of this research, and needs to be discussed separately from the perspective of community governance, because the entire community benefits from the wetland conservation.

The tourism relationship model also identified different development stages of the Trust that can be divided into four parts. The first stage is when the original "Kiritappu Wetland Lovers" identified the attractiveness of the wetland, forming an intra-community group and investing in the wetland at a small scale through leasing activities. This initial stage requires the involvement of only the community, with no need for an intermediary, because of the lack of interaction with extra-community stakeholders.

The second stage was when the "Kiritappu Wetland Lovers" evolved into the "Kiritappu Wetland Fan Club", which started to offer activities involving extra-community stakeholders. This stage is recognized as the initial formation of the intermediary, although the Fan Club did not have the capability to design and offer ecotours.

The organizational form of the intermediary was established when the Center and FKWC started to offer ecotours. Nonetheless, the ability of the intermediary to re-invest was limited, because it was not a jurisdictional body, thus unable to purchase and own the wetland.

The function of the intermediary became fully effective when the Trust was incorporated. The Trust started to purchase and own the wetland, enabling it to take full-fledged reinvestment activities to ensure "circulation" in the model. At the same time, the Trust plays the role of intermediary not only between community and extra-community stakeholders related to tourism, but also including non-tourist stakeholders. Formation of relationships or networks among such stakeholders can be considered as a new form of tourism governance, which requires a separate discussion.

Looking at the evolutionary process of the Kiritappu Wetland Trust, it is clear that the wise use of community resources and the re-investment of profits from the effective use of such resources (e.g. ecotours) can only be achieved when an intermediary is set up to work effectively. That is, setting up an organization to act as an intermediary is only half the battle. Ensuring the organization can carry out the proper "functions" of an intermediary is the critical issue to attaining sustainability in tourism development. 


\section{Conclusion}

The authors proposed a tourism relationship model, which captures relationship between community and extra-community stakeholders. This model has been developed to balance two different perceptions of values-economic value, which extra-community stakeholders tend to favor, and existence value, which communities tend to favor. The intermediary, a sub-system of the model, represents the value of the community, and is expected to continually adjust the relationship between the community and extra-community stakeholders to optimize a balance between the two by providing "circular" and "controlling of flow" mechanisms, which are identified as key functions for successful sustainable tourism.

The Kiritappu Wetland Trust case was analyzed based on this model. The model identifies the key role the Trust plays as a community-based intermediary to balance the economic and existence values. It provides a circular mechanism through creating ecotours, generating economic returns, and reinvesting the returns to the community. It also has strengthened its capability to control the tourism flow by building networks among community, extra-community, and non-tourism stakeholders. This role of networking by the Trust can be considered as a new form of tourism governance.

Development of ecotourism as a tool to conserve the environment and promote economic growth is increasing globally. Japan is not an exception. This tourism relationship model should be a useful framework to plan sustainable development while addressing the needs and values of the destination community. The model clearly identifies the key success factors; namely, whether a circulation mechanism, as illustrated in Figure 1, and a balancing mechanism, as illustrated in Figure 2, exists. The model also can capture the flows of both financial and knowledge capital.

Finally, the introduction of the tourism relationship model sets only an initial analytical framework to understand the relationship between community and extra-community stakeholders. In order to identify the applicability and the limit of the model to various types of destinations, additional study needs to be undertaken. The model's implications for larger communities and for cases where $\mathrm{CBI}$ consists of more than one entity are among the research topics that need to be explored. 


\section{References}

Cabinet Office, Government of Japan. Available from http://www.npo-homepage.go.jp/ (in Japanese)

Fujita M., Tabuchi T. (1997). Regional growth in postwar Japan. Regional Science and Urban Economics, 27(1997), pp643-670.

Ishimori S. (2001). Indigenous Development and Autonomous Tourism (in Japanese). S. Ishimori and N. Nishiyama (Eds.), Selected Research on Heritage Tourism (Senri Ethnological Reports 21), pp.5-19.

Ishimori S. (2002). The Age of Autonomous Tourism (in Japanese). Kagaku, 72(2), pp.706709.

Ministry of Internal Affairs and Communications (2009). Report on Internal Migration in Japan, Annual Report 2008. Available from http://www.stat.go.jp/english/data/idou/3.htm.

Miyauchi, T.(2006). Environemtal Sociology of Legitimacy; Mechanisms for Supporting Commons (in Japanese). Tokyo: Shinyosha.

Shikida A. ,Morishige M., Takagi H. and Miyamoto H.( 2008). Community Ecotourism Development (in Japanese). Kyoto: Gakugei-Syuppansha.

Sato H.(2008). Why is Resource Distribution so Important? H. Sato (Eds.), Resource Site Management (in Japanese). Toshindo, Tokyo, pp1-31.

Weaver, D.(2006). Sustainable Tourism. Oxford: Butterworth-Heinemann.

Weaver, D. and Lawton, L.(2001). Tourism Management. Queensland: John Wiley and Sons Australia Ltd. 


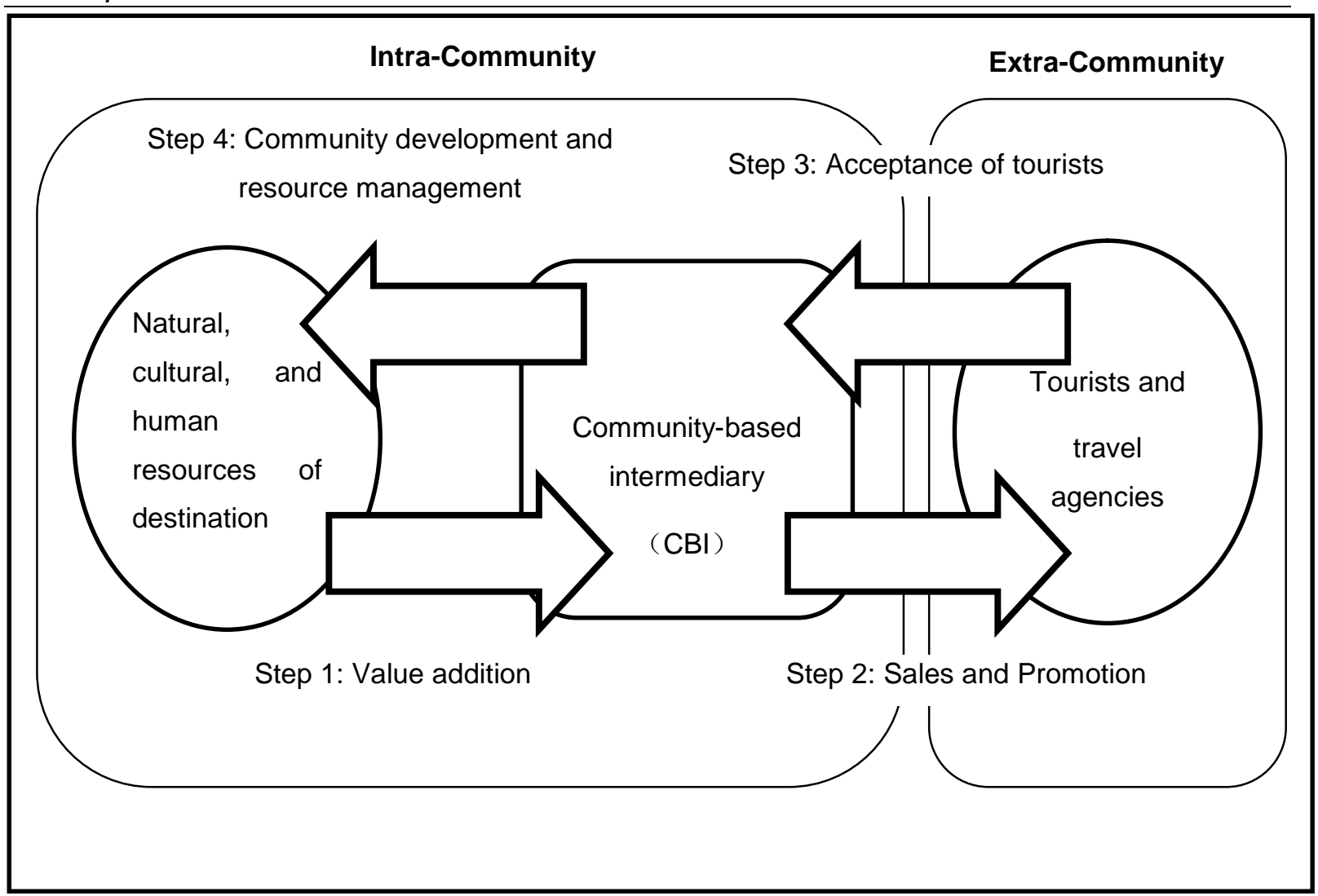

Figure 1: Tourism Relationship Model: Circulation Mechanism

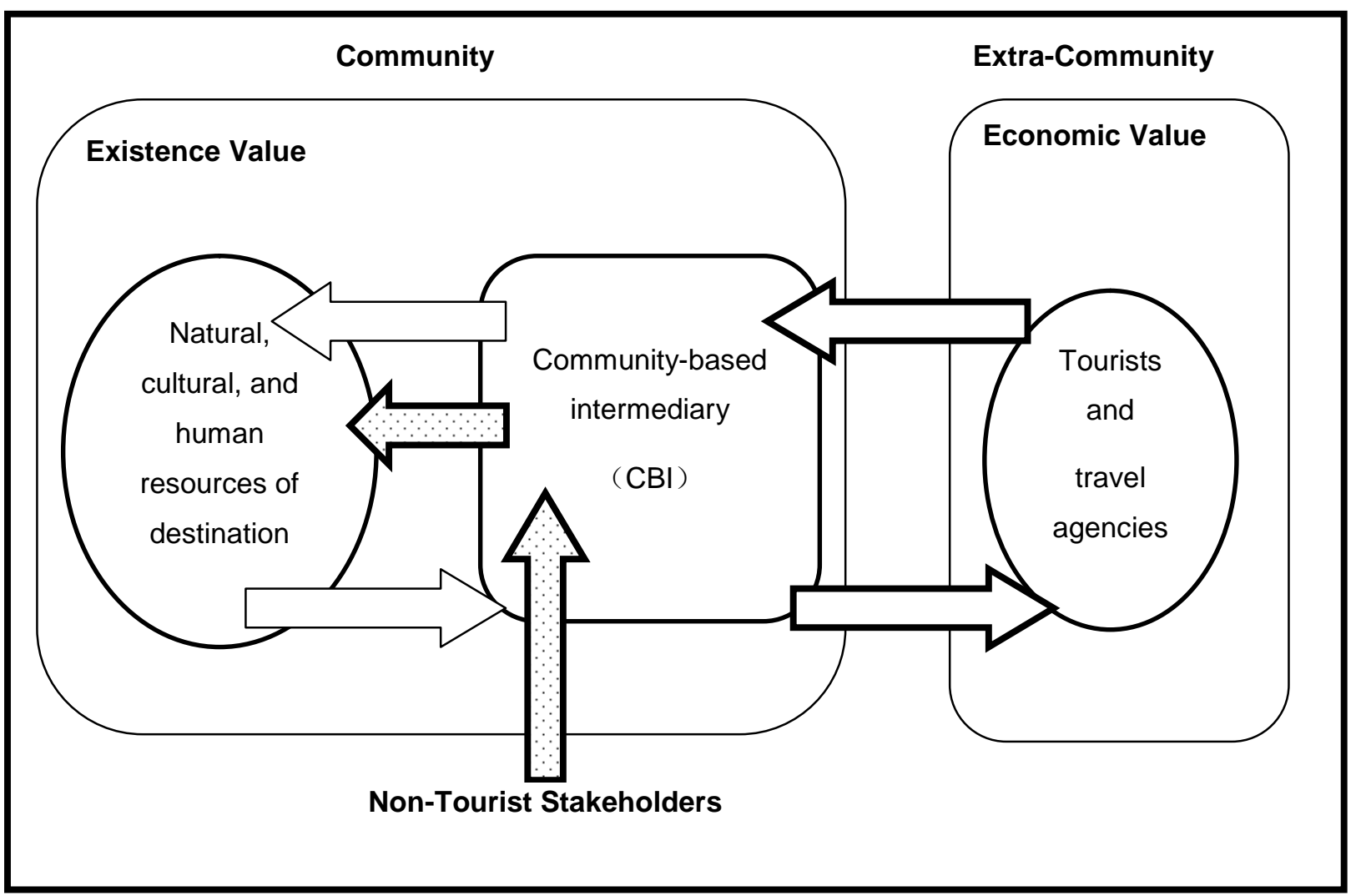

Figure 2: Tourism Relationship Model - CBI as a Flow Controller/Destination Supporter 


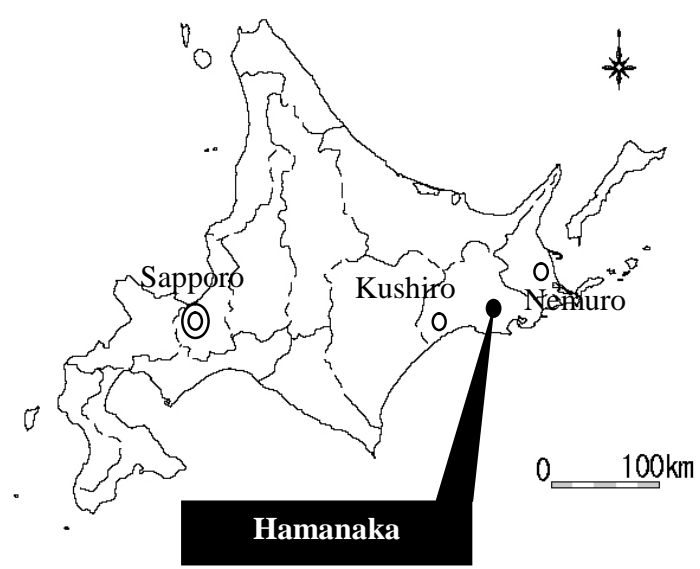

Figure 3 : Map of Hokkaido

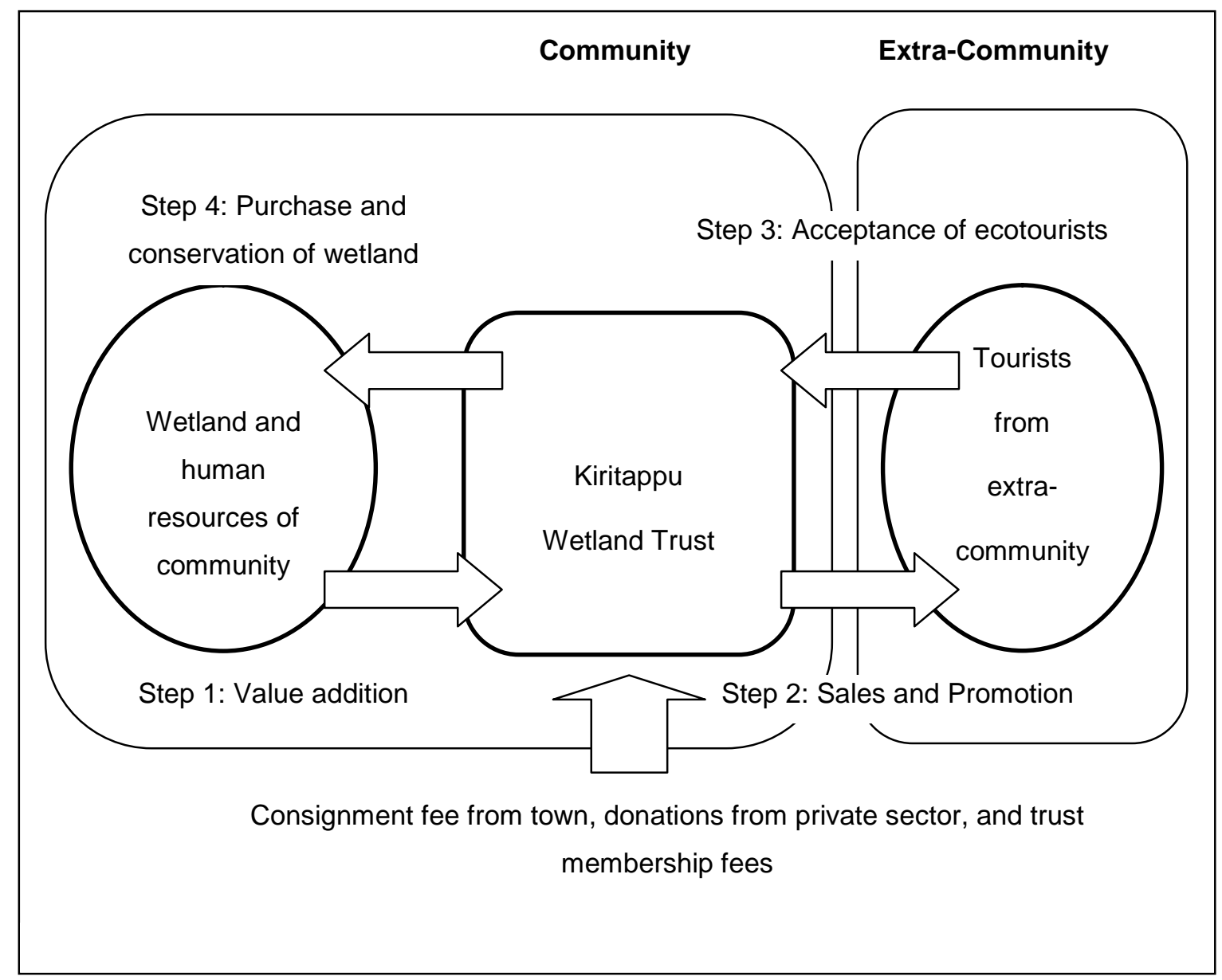

Figure 4: Tourism Relationship Model Applied to Kiritappu Wetland Trust 